\title{
Nutrition assessment of vitamin $A$ and vitamin $D$ in northeast Chinese population based-on SPE/UPLC/PDA
}

\author{
Maoging Wang ${ }^{*}$, Hongyu Chen, Shanshan Du, Xinxin Guo, Jiali Zhao, Changhao Sun and Ying Li
}

\begin{abstract}
Background: The aims of the current study were to assess the nutritional status of 25OHD3 and retinol in a northern Chinese population using our established reliable method for the simultaneous determination of serum 25OHD3 and retinol.

Method: We established a reliable method for the simultaneous determination of 25OHD3 and retinol using SPE and UPLC/PDA; measured the serum levels of 250HD3 and retinol in elementary school students, middle school students, and adults $(n=1181)$ in northern China; and assessed their nutritional status.

Results: Our method had good precision, detection limit, and linear quantitative range and could process 100 samples within $12 \mathrm{~h}$. The average levels of 25OHD3 and retinol were $16.1 \pm 6.7 \mathrm{ng} / \mathrm{ml}$ and $328.1 \pm 117.1 \mathrm{ng} / \mathrm{ml}$, respectively, in all samples. VD deficiency was common, with a prevalence $>60 \%$ in all three age groups, and the high prevalence of VA deficiency (26.1\%) was observed only in the elementary school students.

Conclusions: Vitamin A supplementation should be considered for elementary school students, and vitamin D supplementation is highly recommended for all age groups in Harbin. Our method could be widely adopted in population-based studies and clinical practice.
\end{abstract}

\section{Background}

Deficiencies in Vitamin A (VA) and vitamin D (VD) are important public health problems and the incidences of these deficiencies remain very high throughout the world [1,2]. Women of childbearing age and children are particularly at risk in both developing and developed countries [3]. Rapid and accurate assessments in VA and VD deficiencies were urgently needed for their detrimental effects on human health. Megavitamin therapy and indiscriminate use of vitamins may induce hypervitaminosis or toxicity from vitamins A [4] and D [5], especially dangerous during pregnancysince [6] since vitamins $A$ and $D$ are the fat-soluble vitamins, which are readily stored in the body. Therefore, assessments of VA and VD status at both the individual and population level are important for diagnostic and monitoring

\footnotetext{
* Correspondence: wang_maoqing@126.com; liying_helen@163.com National Key Disciplines of Nutrition and Food Hygiene, Department of Nutrition and Food Hygiene, School of Public Health, Harbin Medical University, 157 Baojian Road, Nangang District, Harbin 150081, People's Republic of China
}

supplementation purposes [7]. For this reason, there is a need for development of reliable biomarkers for assessment of vitamin A and D nutritional status.

Measurement of the liver VA concentration is considered the best indicator of VA nutritional status, but it is not feasible in human studies [8]. In normal healthy human serum, retinol is homeostatically controlled and its concentration will not drop until body stores are significantly compromised, thus it tends to be the most used indicator in human studies $[9,10]$. It was well know that $25 \mathrm{OHD}_{3}$ and $25 \mathrm{OHD}_{2}$ are the two main metabolites of VD. More and more evidences suggested a stronger biological effect of $25 \mathrm{OHD}_{3}$ than $25 \mathrm{OHD}_{2}$ in humans [11]. Furthermore, except in the case of ingestion of vitamin $\mathrm{D}_{2}$ drug preparations, serum $25 \mathrm{OHD}_{2}$ is not observed. Circulating active VD (1,25-dihydroxyvitamin $\left.\mathrm{D}_{3}\right)$ has a short half-life and is closely linked to parathyroid hormone production. Serum levels of 1,25-dihydroxyvitamin $\mathrm{D}_{3}$ do not reflect VD status. Therefore, serum $25 \mathrm{OHD}_{3}$ is the best and the most widely used indicator of nutritional VD status. 
High-performance liquid chromatography (HPLC) and HPLC/ MS (mass spectrometer) have been used for simultaneous determination of serum $25 \mathrm{OHD}_{3}$ and retinol in serum [12-14]. Current methods, however, exhibit some disadvantages and/or limitations [7]. For instance, VA and $25 \mathrm{OHD}_{3}$ are extracted from serum by liquid-liquid extraction (LLE) [10]. Compared with solid-phase extraction (SPE), the pretreatment of serum samples by LLE requires a number of manual transfers of the sample between vials and steps, which are prone to error. Moreover, LLE is laborious, time-consuming and requires appreciable organic solvent. Therefore, SPE is now widely accepted as an attractive alternative to LLE and where there constituted sample residue is separated and analyzed by HPLC. Compared with UPLC, HPLC does require more solvent and separation takes longer [15]. As with LC, LC-MS is an accurate testing method for $25 \mathrm{OHD}_{3}$ and retinol. However, compared with LC, the cost of analysis based on LC/MS is more expensive. A rapid, accurate, and low-cost detection method for serum retinol and $25 \mathrm{OHD}_{3}$ is needed for both population studies and clinical practice.

Considering all above conditions, we developed a simple and rapid method for simultaneous determination of serum $25 \mathrm{OHD}_{3}$ and retinol using SPE, UPLC and diode array detection (PDA). Then, this method was used for the assessment of VA and VD deficiency in three age groups (aged 6-8, 11-13 and 18-65) in Harbin, China.

\section{Methods \\ Establishment of a rapid detection method of vitamin a and vitamin D based-on SPE/UPLC/PDA Reagents and chemicals}

Acetonitrile and methanol (chromatographic grade) were purchased from Honeywell Burdick \& Jackson (Muskegon, MI, USA). Formic acid and ethyl acetate (analytical grade) were from the Beijing Reagent Company (Beijing, China). The ultrapure water was prepared by an ultra clear system (PURELAB Ultra, Veolia Water Solutions \& Technologies, France). Retinol and $25 \mathrm{OHD}_{3}$ were supplied by Sigma-Aldrich (Sigma-Aldrich Co Ltd., Shanghai, China).

\section{Preparation of standard solutions}

Stock solutions of retinol $(1 \mathrm{mg} / \mathrm{ml})$ and $25 \mathrm{OHD}_{3}$ $(1 \mathrm{mg} / \mathrm{ml})$ were prepared with ethanol and stored in amber glass vials at $-20{ }^{\circ} \mathrm{C}$ until analysis. Working solutions in acetonitrile for both standards were prepared in volumetric flasks $(10 \mathrm{ml})$ in the concentration ranges, $2-100 \mathrm{ng} / \mathrm{ml}$ and $20-750 \mathrm{ng} / \mathrm{ml}$, for $25 \mathrm{OHD}_{3}$ and retinol, respectively. The calibration curves were based on 5 concentration levels for each standard compound.

\section{Sample preparation}

First, $200 \mu \mathrm{l}$ acetonitrile was added to each $100 \mu \mathrm{l}$ serum sample. After shaking for $2 \mathrm{~min}$, the samplewas centrifuged at $12000 \mathrm{rpm}$ for $10 \mathrm{~min}$ at $4{ }^{\circ} \mathrm{C}$. The supernatant and $100 \mu \mathrm{l}$ water were both transferred to a new tube. After vortexing for $60 \mathrm{~s}$ and centrifuging at $12000 \mathrm{rpm}$ for $10 \mathrm{~min}$ at $4{ }^{\circ} \mathrm{C}$, the mixed solution was transferred to SPE column (Waters OASIS HLB $\mu$ Elution plates, Waters), which had been previously activated with $200 \mu \mathrm{l}$ ethyl acetate, $200 \mu \mathrm{l}$ methanol, and $200 \mu \mathrm{l}$ water. The SPE $\mu$ Elution plate was then washed with $100 \mu \mathrm{l}$ water and $100 \mu \mathrm{l}$ methanol $(50 \% \mathrm{v} / \mathrm{v})$. The fractions containing $25 \mathrm{OHD}_{3}$ and retinol were eluted from the column using $100 \mu \mathrm{l}$ acetonitrile and collected in a 96 well sample plate. All the extraction procedures were performed under yellow light to minimize decomposition of the analytes.

\section{UPLC/PDA conditions}

Samples were analyzed using a Waters ACQUITY UPLC system equipped with an ACQUITY photodiode array (PDA) (Waters Corporation, Milford, MA, USA). Separation of the extracted sample $(2 \mu \mathrm{L})$ was carried out with a Waters ACQUITY UPLC BEH C18 column $(2.1 \times$ $100 \mathrm{~mm} ; 1.7 \mu \mathrm{m}$ particle size) and a PDA detector. The temperature of UPLC column was maintained at $45{ }^{\circ} \mathrm{C}$. The mobile phase was a mixture of $85 \%$ acetonitrile (eluent A) and $15 \%$ water containing $0.1 \%$ formic acid (eluent B) at a flow rate of $0.35 \mathrm{~mL} / \mathrm{min}$. The PDA detector covered the wavelength range $220-360 \mathrm{~nm}$ to permit simultaneous detection of retinol and $25 \mathrm{OHD}_{3}$ at $325 \mathrm{~nm}$ (retinol) and $256 \mathrm{~nm}\left(25 \mathrm{OHD}_{3}\right)$. The sensitivity, signal linearity, precision, recovery and limits of detection and quantitation were calculated. The lower limits of detection (LLOD) and quantitation (LLOQ) were determined by serial dilutions of pooled serum containing $25 \mathrm{OHD}_{3}$ and retinol.

\section{Intra- and inter-assay precision and accuracy}

The concentrations for the quality control (QC) samples were selected to encompass the entire range of the calibration curves corresponding to the levels anticipated to occur in most samples: low (L), medium (M) and high $(\mathrm{H})$. Replicate analyses $(n=6)$ of three QC samples were conducted to assess the intra-assay precision and accuracy. The precision was evaluated as the coefficient of variation $(\mathrm{CV} \%)$ and the accuracy was calculated as the bias or percent deviation between the nominal and measured concentrations. The recovery of adding standard was assessed by comparing the concentrations of $25 \mathrm{OHD}_{3}$ and retinol in serum samples before and after the addition of known amounts of $25 \mathrm{OHD}_{3}$ and retinol. Five serum samples with $25 \mathrm{OHD}_{3}$ and retinol concentrations ranging from 10 to 50 and $50-400 \mathrm{ng} / \mathrm{mL}$ were 
used. The concentrations of $25 \mathrm{OHD}_{3}$ and retinol added to each sample were 10,20 and $50 \mathrm{ng} / \mathrm{mL}$, and 50,100 and $400 \mathrm{ng} / \mathrm{mL}$, respectively.

The linearity measuring ranges were evaluated by constructing standard curves for $25 \mathrm{OHD}_{3}$ and retinol. The response was considered to be linear if the correlation coefficient was greater than 0.99 .

\section{Verification of UPLC/PDA on a UPLS/Xevo ${ }^{\mathrm{TM}}$ TQ MSMS}

Our method using SPE/UPLC/PDA requires verification through analysis on another platform or the use of external QA samples. LC-MS/MS has already been introduced as a simple, rapid, and robust reference method for the determination of steroid hormones, such as $25 \mathrm{OHD}_{3}$. Therefore, LC-MS/MS was used as the reference method to validate our established method. The 30 participants were randomly selected, pretreatment and separated the same as above method. Mobile phase A included $15 \%$ water $+2 \%$ formic acid, and mobile phase B included $85 \%$ acetonitrile $+2 \%$ formic acid. But, the serum concentrations of 25OHD3 and retinol were measured on a UPLS/Xevo ${ }^{\mathrm{m}}$ TQ MSMS (Waters Corporation, Milford, MA, USA) in ESI positive mode. The conditions of the Xevo ${ }^{\text {tm }}$ TQ MSMS are shown in Additional file 1: Table S1. To illustrate the magnitude of differences between UPLDA/PDA and UPLC/TQ MSMS, the differences, expressed as a percentage of the LC-MS/MS value, were plotted [16]. Wilcoxon matchedpairs signed-rank test was used to analyze the differences between the two methods.

\section{Nutrition assessment of VA and VD in northeast Chinese population \\ Study subjects}

One across-sectional study was carried out from June to July 2013 in Xiang fang district, Harbin. It is the biggest city in northern China $\left(44^{\circ} \mathrm{N} \sim 46^{\circ} \mathrm{N}\right)$. Using the group sampling method, a total of 600 adults (aged 35-65) from Haping health service center, 274 students (aged
12-17) from Rongzhi middle school, and 307 students (aged 6-11) from Xinghua elementary school were randomly selected. A total of 1181 participants, 600 adults, 274 middle school students and 307 elementary school students were included in current students. Fasting blood samples were collected from all participants before 9:00 am after $\geq 10 \mathrm{~h}$ fasting. All blood samples were centrifuged at $2500 \times \mathrm{g}$ for $15 \mathrm{~min}$ at room temperature within $30 \mathrm{~min}$ after collection, then the supernatant was stored at $-80{ }^{\circ} \mathrm{C}$ until measurements. Serums were pre-treated and $25 \mathrm{OHD}_{3}$ and retinol were determined by the described above method. All experiments including all relevant details were performed in accordance with relevant guidelines and regulations.

\section{Nutrition assessment}

Serum retinol and $25 \mathrm{OHD}_{3}$ were used in the assessment of VA and VD nutrition status. Sufficient, insufficient, mild deficient and deficient VA were defined as serum retinol $\geq 300,200 \sim 300,100 \sim 200$, and $<100 \mathrm{ng} / \mathrm{ml}$. Sufficiency, insufficiency, deficiency, and severe deficiency in VD were defined as serum $25 \mathrm{OHD}_{3} \geq 30,20 \sim 30,10 \sim$ 20 , and $<10 \mathrm{ng} / \mathrm{ml}$.

\section{Results \\ Quantitative detection of 250HD3 and retinol based on SPE/UPLC/PDA}

As shown Fig. 1, 25OHD 3 and retinol were separated by UPLC C18 column in $6 \mathrm{~min}$. The retention times of $25 \mathrm{OHD}_{3}$ and retinol were 1.76 and $2.16 \mathrm{~min}$ (Fig. 1). Acetonitrile $(200 \mu \mathrm{l})$ was added to serum $(100 \mu \mathrm{l})$ for deproteinization. Therefore, the polarity of the supernatant was low (acetonitrile: water $\geq 2: 1$ ). When sample solutions were directly transferred to the SPE column, $25 \mathrm{OHD}_{3}$ and retinol may not be completely retained on the column. To decrease the potential losses of $25 \mathrm{OHD}_{3}$ and retinol in sample processing, $100 \mu \mathrm{l}$ water was added to the acetonitrile supernatant to decrease the polarity of the solution. Based on the same reasoning, 50\%

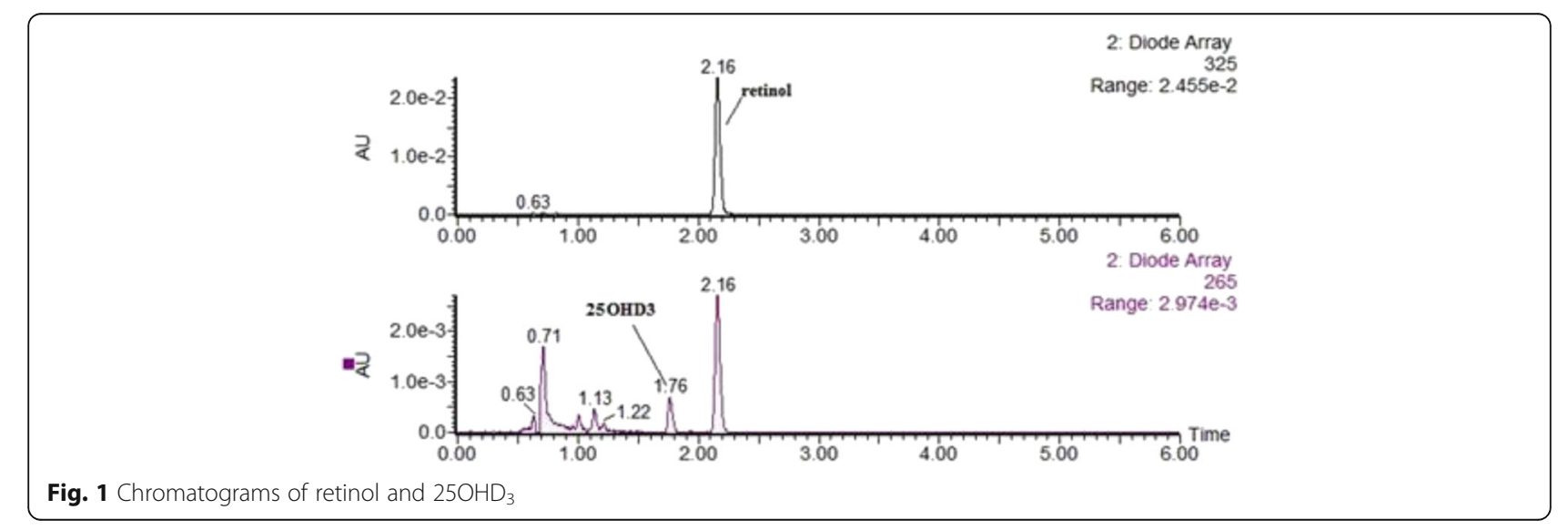


methanol was used as a second eluant. The average recoveries for 10,20 and $50 \mathrm{ng} / \mathrm{ml} 25 \mathrm{OHD}_{3}$ were $97.8 \%$, $101.7 \%$ and $94.4 \%$, respectively. The average recoveries for 50,100 and $400 \mathrm{ng} / \mathrm{ml}$ retinol were $98.1 \%, 97.2 \%$ and $96.5 \%$, respectively. Therefore, both compounds exhibited acceptable recoveries for the Oasis HLB SPE 96well elution plate.

The relative standard deviation $(n=6)$ of the inter-day precision for $25 \mathrm{OHD} 3$ and retinol were $4.69 \%$ and 3 . $72 \%$. The relative standard deviation of intra-day precision for 25OHD3 and retinol were 5.26\% and $4.62 \%$. Also good linearity of quantification $(\mathrm{R} 2>0.99)$ were obtained over the concentration ranges 2 to $100 \mathrm{ng} / \mathrm{ml}$ $\left(25 \mathrm{OHD}_{3}\right)$ and 25 to $740 \mathrm{ng} / \mathrm{ml}$ (retinol). The regression equations were $\mathrm{y}=0.877 \mathrm{x}+3.6836$ (Fig. 2a) and $\mathrm{y}=0$. $649 x-3.1755$ (Fig. 2b). The LODs for $25 \mathrm{OHD}_{3}$ and retinol were $1 \mathrm{ng} / \mathrm{ml}$ and $25 \mathrm{ng} / \mathrm{ml}$, respectively.

\section{Quantitative detection of 250HD3 and retinol by SPE/ UPLC/XEVO TQ MS}

The relative standard deviation $(n=6)$ and the inter-day precision for $25 \mathrm{OHD}_{3}$ and retinol were $3.63 \%$ and $2.15 \%$, respectively. The relative standard deviation of the intraday precision for 25OHD3 and retinol were $4.65 \%$ and 2 . $99 \%$, respectively. Good linearity for the quantification $(\mathrm{R} 2>0.99)$ was obtained over 2.5 to $100 \mathrm{ng} / \mathrm{ml}\left(25 \mathrm{OHD}_{3}\right)$

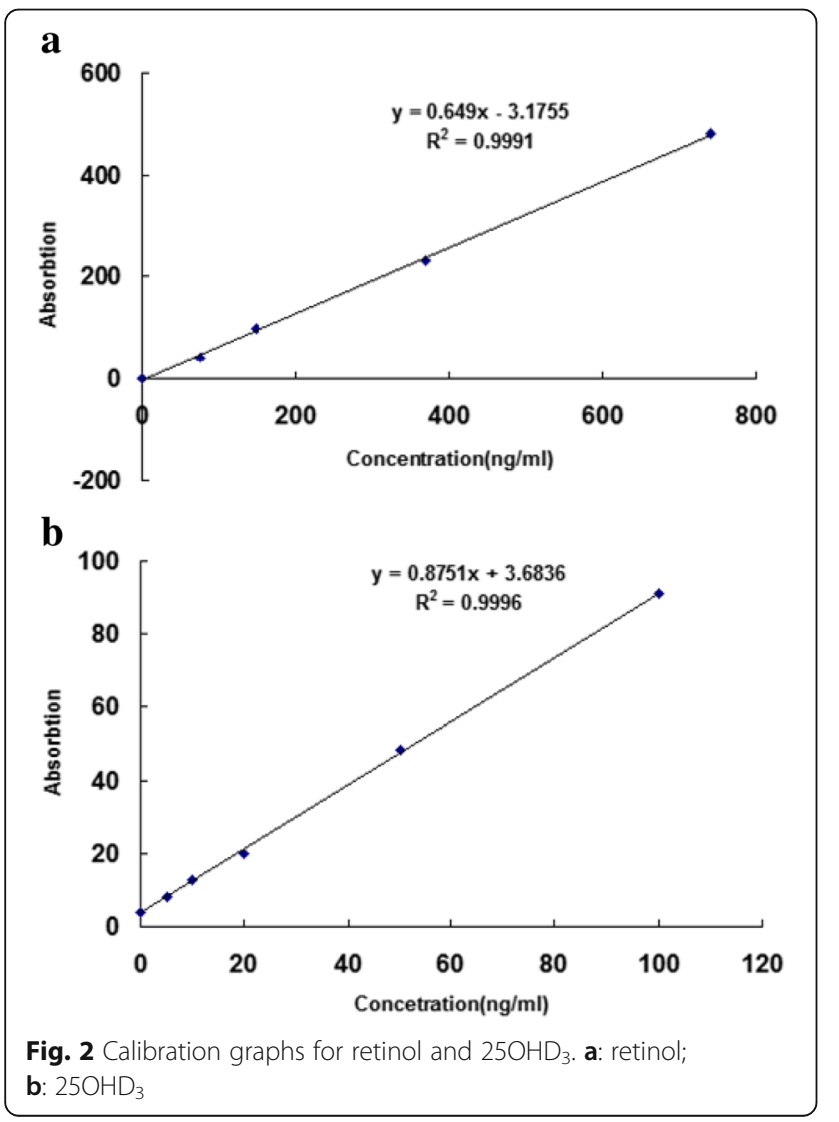

and 4 to $800 \mathrm{ng} / \mathrm{ml}$ (VA). The regression equations were $y=14.3959 x+651.83$ (VA Additional file 1: Figure S1A) and $y=15.77 x-26.52\left(25 \mathrm{OHD}_{3}\right.$ Additional file 1: Figure S1B). The LODs for $25 \mathrm{OHD}_{3}$ and retinol were $1 \mathrm{ng} / \mathrm{ml}$ and $4 \mathrm{ng} / \mathrm{ml}$, respectively.

\section{Comparison of UPLS/PDA and UPLC/MS}

Plots of the \% differences against the LC-MS/MS values were applied to 30 samples (Additional file 1: Figure S2). No significant differences $(p>0.9)$ in 25OHD3 and retinol were observed between UPLC/PDA and UPLC/MS by Wilcoxon matched-pairs signed-rank test. These results indicate that our method was reliable in simultaneously determining serum 25OHD3 and retinol.

\section{Nutritional assessment of VA and VD in a northern Chinese population}

Serum $25 \mathrm{OHD}_{3}$ and retinol were determined in 307 elementary school students, 274 middle school students, and 600 adults. The mean levels of serum $25 \mathrm{OHD}_{3}$ were $16.1 \pm 6.7 \mathrm{ng} / \mathrm{mL}, 17.8 \pm 7.3 \mathrm{ng} / \mathrm{mL}, 15$. $3 \pm 5.7 \mathrm{ng} / \mathrm{mL}$, and $15.4 \pm 6.1 \mathrm{ng} / \mathrm{mL}$ in the entire cohort, elementary school students, middle school students, and adults, respectively (Table 1). Significant differences were observed between these three groups $(P<0.001)$. The means between any two groups also differed (all $P$-values $=0.000$ ), except between adults and middle school students $(P$-values $=1.000)$. These results indicate that elementary school students have higher serum levels of $25 \mathrm{OHD}_{3}$ compared with middle school students and adults. As shown in Table 2, with regard to serum vitamin D, severe deficiency $(<$ $10 \mathrm{ng} / \mathrm{mL})$ and deficiency [(10-20) $\mathrm{ng} / \mathrm{mL}]$ were detected in $12.7 \%$ and $64.7 \%$ of participants, respectively, and $19.4 \%$ and $3.2 \%$ of participants were vitamin Dinsufficient $[(20-30) \mathrm{ng} / \mathrm{mL}]$ and -sufficient $(>30 \mathrm{ng} / \mathrm{mL}$ ). Although elementary school students had the highest serum $25 \mathrm{OHD}_{3}$ among the three groups, over $65 \%(8.5 \%$ severe deficiency and $58.3 \%$ deficiency) were considered

Table 1 Serum 25OHD3 and retinol levels of all participants

\begin{tabular}{lllll}
\hline Participants & $\begin{array}{l}25 \mathrm{OHD}_{3} \\
(\mathrm{ng} / \mathrm{ml})\end{array}$ & $P$-value & $\begin{array}{l}\text { Retinol } \\
(\mathrm{ng} / \mathrm{ml})\end{array}$ & $P$-value \\
\hline Elementary school students & $17.8 \pm 7.3$ & $0.000^{\mathrm{a}}$ & $255.5 \pm 78.2$ & $0.000^{\mathrm{a}}$ \\
Middle school students & $15.4 \pm 6.1$ & $0.000^{\mathrm{b}}$ & $319.8 \pm 113.3$ & $0.000^{\mathrm{b}}$ \\
Adults & $15.3 \pm 5.7$ & $0.000^{\mathrm{c}}$ & $369.1 \pm 116.8$ & $0.000^{\mathrm{c}}$ \\
Total & $16.1 \pm 6.7$ & $1.000^{\mathrm{d}}$ & $328.1 \pm 117.1$ & $0.000^{\mathrm{d}}$ \\
\hline
\end{tabular}

${ }^{a}$ results of One-way ANOVA for the comparison of elementary school students, middle school students, and adults

${ }^{b}$ results of One-way ANOVA (Bonferroni correction) for the comparison with elementary school students

${ }^{c}$ results of One-way ANOVA (Bonferroni correction) for the comparison with elementary school students

${ }^{d}$ results of One-way ANOVA (Bonferroni correction) for the comparison with middle school students 
Table 2 Nutrition assessment of Vitamin A in three age groups

\begin{tabular}{llllll}
\hline Participants & Deficiency & $\begin{array}{l}\text { Marginal } \\
\text { deficiency }\end{array}$ & Insufficiency & Sufficiency & P-value \\
\hline $\begin{array}{l}\text { Elementary } \\
\text { school } \\
\text { students }\end{array}$ & $3(1.0)$ & $77(25.1)$ & $143(46.6)$ & $84(27.4)$ & $0.000^{\mathrm{a}}$ \\
$\begin{array}{l}\text { Middle } \\
\text { school } \\
\text { students }\end{array}$ & $0(0)$ & $33(12.0)$ & $103(37.6)$ & $138(50.4)$ & $0.000^{\mathrm{b}}$ \\
$\begin{array}{l}\text { Adults } \\
\text { Total }\end{array}$ & $0(0)$ & $22(3.7)$ & $156(26.0)$ & $422(70.3)$ & $0.000^{\mathrm{c}}$ \\
\hline
\end{tabular}

Note: all data were shown in $\mathrm{n}(\%)$; deficiency: $<100 \mathrm{ng} / \mathrm{ml}$; marginal deficiency: 100 $200 \mathrm{ng} / \mathrm{ml}$; insufficient: $200 \sim 300 \mathrm{ng} / \mathrm{ml}$; sufficient: $\geq 300 \mathrm{ng} / \mathrm{ml}$

a results of Chi-Square tests for the comparison of elementary school students, middle school students, and adults (the cut-off value of $P$ is 0.05 )

${ }^{\mathrm{b}}$ results of Chi-Square tests for the comparison with elementary school students (the cut-off value of $P$ with Bonferroni correction is 0.05/3)

${ }^{c}$ results of Chi-Square tests for the comparison with elementary school students (the cut-off value of $P$ with Bonferroni correction is $0.05 / 3$ )

${ }^{d}$ results of Chi-Square tests for the comparison with middle school students (the cut-off value of $P$ with Bonferroni correction is $0.05 / 3$ )

deficient. Adults and middle school students were even more lacking in vitamin D.

The mean levels of serum retinol were $328.1 \pm 117.1 \mathrm{ng} /$ $\mathrm{mL}, 255.5 \pm 78.2,319.8 \pm 113.3$, and $369.1 \pm 116.8 \mathrm{ng} / \mathrm{mL}$ in the entire pool, elementary school students, middle school students, and adults, respectively. Based on the multiple comparisons, statistically significant differences in the means of serum retinol concentration between any two groups (all $P$-values $=0.000$ ) were observed. Unlike serum $25 \mathrm{OHD}_{3}$, the highest and lowest levels of serum retinol were seen in adults and elementary school students, respectively. As shown in Tables 3, 0.3\% and $11.2 \%$ of participants had levels under $100 \mathrm{ng} / \mathrm{mL}$ (deficiency) and 100 $200 \mathrm{ng} / \mathrm{mL}$ (marginal deficiency), respectively. Also, $34.0 \%$ and $54.5 \%$ of participants had insufficient

Table 3 Nutrition assessment of Vitamin D in three age groups

\begin{tabular}{llllll}
\hline Participants & $\begin{array}{l}\text { Severe } \\
\text { deficiency }\end{array}$ & Deficiency & Insufficiency & Sufficiency & P-value \\
\hline $\begin{array}{l}\text { Elementary } \\
\text { school } \\
\text { students }\end{array}$ & $26(8.5)$ & $179(58.3)$ & $84(27.4)$ & $18(5.9)$ & $0.000^{\mathrm{a}}$ \\
$\begin{array}{l}\text { Middle } \\
\text { school } \\
\text { students }\end{array}$ & $47(17.2)$ & $168(61.3)$ & $53(19.3)$ & $6(2.2)$ & $0.001^{\mathrm{b}}$ \\
Adults & $76(12.7)$ & $416(69.3)$ & $94(15.7)$ & $14(2.3)$ & $0.000^{c}$ \\
Total & $150(12.7)$ & $764(64.7)$ & $229(19.4)$ & $38(3.2)$ & $0.110^{d}$ \\
\hline
\end{tabular}

Note: all data were shown in $\mathrm{n}(\%)$; severe deficiency: $<10 \mathrm{ng} / \mathrm{ml}$; deficiency: 10 $20 \mathrm{ng} / \mathrm{ml}$; insufficient: $20 \sim 30 \mathrm{ng} / \mathrm{ml}$; sufficient: $\geq 30 \mathrm{ng} / \mathrm{ml}$

${ }^{a}$ results of $\mathrm{Chi}$-Square tests for the comparison of elementary school students, middle school students, and adults (the cut-off value of $P$ is 0.05 )

${ }^{b}$ results of Chi-Square tests for the comparison with elementary school students (the cut-off value of $P$ with Bonferroni correction is $0.05 / 3$ )

${ }^{c}$ results of $\mathrm{Chi}$-Square tests for the comparison with elementary school students (the cut-off value of $P$ with Bonferroni correction is $0.05 / 3$ )

${ }^{d}$ results of $\mathrm{Chi}$-Square tests for the comparison with middle school students (the cut-off value of $P$ with Bonferroni correction is $0.05 / 3$ )
(200-300) $\mathrm{ng} / \mathrm{mL}$ and sufficient (> $300 \mathrm{ng} / \mathrm{mL}$ ) serum VA, respectively. More than $88 \%$ of middle school students and adults had sufficient nutritional status. However, $1.0 \%$ and $25.1 \%$ of elementary school students were considered to have deficiency and mild deficiency, respectively. The VA nutritional status of the population in Harbin was better than that of VD, and most of the population had good nutritional sufficiency.

\section{Discussion}

VA and VD are essential nutrients, and insufficiency of these vitamins is associated with several acute and chronic diseases. Yet, the incidence of VA and VD deficiency has remained very high throughout the world. Among all causes of disease, it is the most frequently overlooked. Therefore, a high-throughput, low-cost method for determining retinol and $25 \mathrm{OHD}_{3}$ is needed. The key contribution of our study was the establishment of an easy and fast method for routine measurements of $25 \mathrm{OHD}_{3}$ and retinol, based on SPE and UPLC/PDA, with which we assessed the nutritional status of VA and VD in a northern Chinese population.

Based on optimized instrument parameters, our method showed good precision and excellent accuracy in simultaneously determining the metabolites of VA and VD. The average levels of retinol and $25 \mathrm{OHD}_{3}$ in serum range from 100 to $500 \mathrm{ng} / \mathrm{ml}$ and $10-35 \mathrm{ng} / \mathrm{ml}$, respectively; thus, the sensitivity (retinol: $20 \mathrm{ng} / \mathrm{ml}$; $25 \mathrm{OHD}_{3}: 2 \mathrm{ng} / \mathrm{ml}$ ) of this new method is satisfactory for population-based and clinical detection. Compared with $\mathrm{LC} / \mathrm{MC}$, this UPLC/PDA method is less expensive for large population studies. It also decreased the use of toxic organic solvents and shortened the sample preparation time. Samples could be prepared within $15 \mathrm{~min}$, and the separation time was within $3 \mathrm{~min}$. The proposed method, based on SPE/UPLC/PDA, can process 100 serum samples within $12 \mathrm{~h}$. If increased capacity is required, the system can run reliably overnight, unsupervised and doubling sample throughput.

Another important advantage of this method is its lower sample volume consumption (100 $\mu \mathrm{l}$ per sample), which is an important factor analytically and clinically. Compared with liquid-liquid extraction, the cost of SPE cartridges can be offset by the savings in labor and reagent expenses. Therefore, this simple and fast method for measuring serum retinol and 25OHD3 is suitable and can be recommended for nutritional assessments in population-based studies and clinical practice.

VA and VD are necessary to maintain health, and their deficiency may cause various conditions [17]. Describing the status of VA and VD in a population has tremendous significance for public health. Serum retinol and $25 \mathrm{OHD}_{3}$ were determined in 307 elementary school students, 274 middle school students and 600 adults in this 
study. According to WHO standards, serum retinol concentrations are classified as $\geq 1.05 \mu \mathrm{mol} / \mathrm{L}(300 \mathrm{ng} / \mathrm{ml})$ for normal, $0.70-1.05 \mu \mathrm{mol} / \mathrm{L}(200-300 \mathrm{ng} / \mathrm{ml})$ for marginal, and $<0.70 \mu \mathrm{mol} / \mathrm{l}(200 \mathrm{ng} / \mathrm{ml})$ for deficient. Elementary school students (aged 6-11 years) had the lowest levels of serum VA $(255.5 \pm 78.2 \mathrm{ng} / \mathrm{ml})$, the highest prevalence of VA deficiency ( $1 \%$ deficiency; $25.1 \%$ marginal deficiency). In contrast, $12 \%$ of middle school students and $3.7 \%$ of adults were considered marginally deficient. The China National Nutrition and Health Survey (2010-2013) has estimated the prevalence of serum VA deficiency $(<200 \mathrm{ng} / \mathrm{mL})$ to be $8.04 \%$ in $6-11$-yearolds [18]. The mean levels VA in the population of Harbin City (aged 6-11 years: $255.5 \mathrm{ng} / \mathrm{ml}$; aged 1117 years: $319.8 \mathrm{ng} / \mathrm{ml}$ ) were lower than the national mean levels (aged $6-11$ years: $1.46 \mu \mathrm{mol} / \mathrm{L}(417 \mathrm{ng} / \mathrm{ml})$; 12-17 years: $1.54 \mathrm{umol} / \mathrm{L}(440.4 \mathrm{ng} / \mathrm{ml}))$. The prevalence of mild VA deficiency (25\%) in the Harbin population (ages 6-11 years) was higher than the national average (16.54\%). But, the prevalence of vitamin A deficiency (1\% and $0 \%$ ) in Harbin (ages 6-11 years and $12-17$ years, respectively) was lower than the national average (8.04\% and 7.18\%) [19]. Previous studies have indicated that VA deficiency decreases with age [20]. Our results indicated a similar trend, wherein severe VA deficiency was only observed in younger school-age students (6-11 years), and marginal deficiency was observed in elder students (12-17 years), but there was no deficiency in adults.

VA plays an important role in the adverse effects of virus and bacterial infections [21] and as parasitic infections [22]. Vitamin A deficiency can affect immune function and lead to higher morbidity and mortality due to respiratory and digestive tract infections in children [23, 24]. Therefore, we strongly recommended appropriate VA supplementation for elementary school students in Harbin.

Previous studies have documented severe VD deficiency in all age groups worldwide. In China, the prevalence of serum $25 \mathrm{OHD}_{3}$ deficiency is higher than $50 \%$ in all age groups [25, 26], reaching $85.8 \%, 97 \%$, and $89.7 \%$ in schoolaged students, adolescents, and adults, respectively, in some remote and low-income regions [27-29]. The prevalence of vitamin D deficiency in schoolchildren (ages 7 to $11 \mathrm{y}$ ) is $56.4 \%$ in 2013 [30] and $45.85 \%$ of (ages 1 to $10 \mathrm{y}$ ) [31] in Harbin. The prevalence of suboptimal vitamin D (vitamin D deficiency and insufficiency) is $74.7 \%$ (ages 20 to $74 \mathrm{y}$ ) [32] and $87.35 \%$ (ages 1 to $10 \mathrm{y}$ ) [31] in Harbin. In our study, we observed a high prevalence of VD deficiency $(66.8 \%, 78.5 \%$, and $82.0 \%$, respectively) was observed in elementary school students, middle school students, and adults in this study. The major natural source of vitamin $\mathrm{D}$ is photosynthesis in the skin following ultraviolet B solar irradiation. Harbin is located at high latitudes and in a cold region (N44-46 $6^{\circ}$. The lower level of $25 \mathrm{OHD}_{3}$ from skin photosynthesis in Harbin residents can be explained in part by the shortage of sun exposure and less outdoor activity during long winters.

A small amount of VD is acquired from food. The most significant dietary sources of VD are oily fish and cod liver oil. However, the typical Harbin diet lacks these foods. Low dietary vitamin D intake, combined with the lack of skin synthesis for half of the year, is reflected in the disturbingly high prevalence of VD insufficiency throughout Harbin. Vitamin D deficiency is associated with skeletal disease, rickets [33], and osteomalacia. Several observational studies have shown that VD deficiency also increases the probability of chronic non-communicable diseases, such as stroke [34], diabetes [32], and hypertension [35, 36]. Therefore, monitoring and assessing the status of VA and VD in the population has great public health significance. Based our results, we strong recommended VD supplementation for all three age groups in Harbin.

\section{Conclusions}

Our method is a simple and rapid approach for measuring serum retinol and $25 \mathrm{OHD}_{3}$. It is reliable and can be applied in population-based studies and clinical practice. In northern China, VA deficiency is prevalent in elementary school students, and VD deficiency is common in the entire population and is a global public health problem for all age groups. Supplementing vitamin A in elementary school students and VD in all age groups is imperative for improving public health. We strongly recommend this fast and simple method for measuring VA and VD in other populations.

\section{Additional file}

Additional file 1: Table S1. TQ MS condition of detecting of serum retinol and 25OHD3. Figure S1. Calibration graphs for retinol and 25OHD3. Figure S2. Plots of the percentage difference in 25OHD3 and retinol concentrations measured in ULPC/PDA by UPLC/MS-MS. (DOCX $125 \mathrm{~kb})$

\section{Abbreviations}

LLE: Liquid-liquid extraction; MS: Mass spectrometer; PDA: Photodiode array; QC: Quality control; SPE: Solid-phase extraction; UPLC: Ultra-performance liquid chromatography; VA: Vitamin A; VD: Vitamin D

\section{Acknowledgements \\ Heilongjiang Province Disease Prevention and Control Center is gratefully acknowledged for their sample collection. Fan Wang is gratefully acknowledged for her polish the language. \\ Funding \\ This study was financed by National Natural Science Foundation of China (81102113) and Natural Science Foundation of Heilongjiang Province ( $\mathrm{H} 2015012)$. The funding bodies had no role in the design of the study and collection, analysis, and interpretation of data and in writing the manuscript.}

\section{Availability of data and materials}

The datasets used and/or analysed during the current study are available from the corresponding author on reasonable request. 


\section{Authors' contributions}

MQW designed the study and the analyses, wrote the manuscript. YL and CHS participated in the design of the study and and contributed to the drafting of the manuscript. HYC, SSD, JLZ and XXG participated in the sample preparation, detection and organized part of the statistical analysis. All the authors approved the final manuscript for submission.

\section{Ethics approval and consent to participate}

We carried out this study after obtaining informed written consent from study subjects and approval from the Human Research and Ethics Committee of Harbin Medical University. Informed consents were obtained from all individual participants included in the study. Participates' under 16 years old informed consents were obtained from their parents or legal guardians.

\section{Consent for publication}

Not applicable.

\section{Competing interests}

The authors declare that they have no competing interest.

\section{Publisher's Note}

Springer Nature remains neutral with regard to jurisdictional claims in published maps and institutional affiliations.

\section{Received: 7 December 2017 Accepted: 16 March 2018} Published online: 27 March 2018

\section{References}

1. Yang C, Chen J, Guo N, Liu Z, Yun C, Li Y, Piao J, Yang X. Comparison on the status of vitamin a in 6- to 13-year-old children between 2002 and 2012 in China. Nutr J. 2015:15(1):50.

2. Mc Lean E, Cogswell M, Egli I, Wojdyla D, de Benoist B. Worldwide prevalence of anaemia, WHO vitamin and mineral nutrition information system, 1993-2005. Public Health Nutr. 2009;12(4):444-54

3. Organization $\mathrm{WH}$ : Global prevalence of vitamin a deficiency in populations at risk 1995-2005: WHO global database on vitamin a deficiency. 2009.

4. Denke MA. Dietary retinol-a double-edged sword. JAMA. 2002;287(1):102-4

5. Pettifor JM, Bikle DD, Cavaleros M, Zachen D, Kamdar MC, Ross FP. Serum levels of free 1, 25-dihydroxyvitamin D in vitamin D toxicity. Ann Intern Med. 1995;122(7):511-3.

6. Allen $\mathrm{LH}$, Haskell M. Estimating the potential for vitamin a toxicity in women and young children. J Nutr. 2002;132(9 Suppl):2907S.

7. Mata-Granados J, Luque de Castro M, Quesada Gomez J. Inappropriate serum levels of retinol, a-tocopherol, 25 hydroxyvitamin D3 and 24, 25 dihydroxyvitamin D 3 levels in healthy Spanish adults: simultaneous assessment by HPLC. Clin Biochem. 2008;41(9):676-80.

8. Tanumihardjo SA. Vitamin a: biomarkers of nutrition for development. Am J Clin Nutr. 2011:94(2):658S-65S.

9. Abrahamsson L, Andersson A. Principles of nutritional assessment. Journal of Human Nutrition \& Dietetics. 2006:19(1):72-3.

10. De PS, Dary O. Biochemical indicators of vitamin a deficiency: serum retinol and serum retinol binding protein. J Nutr. 2002;132(9 Suppl):2895S.

11. Trang HM, Cole DE, Rubin LA, Pierratos A, Siu S, Vieth R. Evidence that vitamin D3 increases serum 25-hydroxyvitamin D more efficiently than does vitamin D2. Am J Clin Nutr. 1998;68(4):854-8.

12. Granado-Lorencio F, Olmedilla-Alonso B, Herrero-Barbudo C, Blanco-Navarro I, Blázquez-García S, Pérez-Sacristán B. Simultaneous determination of vitamins a, E and 25-OH-vitamin D: application in clinical assessments. Clin Biochem. 2006;39(2):180-2.

13. Alvarez JC, De MP. Rapid and sensitive high-performance liquid chromatographic method for simultaneous determination of retinol, a-tocopherol, 25-hydroxyvitamin D_3 and 25-hydroxyvitamin D_2 in human plasma with photodiode-array ultraviolet detection. Journal of Chromatography B Biomedical Sciences \& Applications. 2001;755(1-2):129-35

14. Knox S, Harris J, Calton L, Wallace AM. A simple automated solid-phase extraction procedure for measurement of 25-hydroxyvitamin D3 and D2 by liquid chromatography-tandem mass spectrometry. Ann Clin Biochem. 2009;46(Pt 3):226.
15. Granado-Lorencio F, Herrero-Barbudo C, Blanco-Navarro I, Pérez-Sacristán B. Suitability of ultra-high performance liquid chromatography for the determination of fat-soluble nutritional status (vitamins a, E, D, and individual carotenoids). Anal Bioanal Chem. 2010;397(3):1389-93.

16. Roth HJ, Schmidtgayk H, Weber H, Niederau C. Accuracy and clinical implications of seven 25-hydroxyvitamin D methods compared with liquid chromatography-tandem mass spectrometry as a reference. Ann Clin Biochem. 2008;45(2):153-9.

17. Pakseresht M, Kolahdooz F, Gittelsohn J, Roache C, Corriveau A, Sharma S. Improving vitamin a and D intake among Inuit and Inuvialuit in Arctic Canada: evidence from the healthy foods north study. J Epidemiol Community Health. 2015;69(5):453-9.

18. Yang C, Chen J, Guo N, Liu Z, Yun C, Li Y, Piao J, Yang X. Comparison on the status of vitamin a in 6- to 13-year-old children between 2002 and 2012 in China. Nutr J. 2016:15(1):50.

19. Zhang Y, Liu XB, Yang LC, Chen J, Wang R, Yang XG, Piao JH, Mao DQ. Study on vitamin A nutritional status of 6- to 17-year-old urban children and adolescents between 2010 and 2012 in China. Chinese J Prev Med. 2017;51(2):117-20

20. Hu W, Tong S, Oldenburg B, Feng X. Serum vitamin a concentrations and growth in children and adolescents in Gansu Province, China. Asia Pac Clin Nutr. 2001:10(1):63-6.

21. Semba RD. Vitamin a and immunity to viral, bacterial and protozoan infections. Proc Nutr Soc. 1999:58(3):719-27.

22. Almekhlafi HM, Surin J, Sallam A, Abdullah A, Mahdy M, Hasan CA. Impact of intestinal parasitic infections on vitamin a status among aboriginal schoolchildren in rural peninsular Malaysia. Am J Trop Med Hyg. 2008;79(6): 346.

23. Ramakrishnan $U$, Martorell $R$. The role of vitamin a in reducing child mortality and morbidity and improving growth. Salud Publica Mex. 1998; 40(2):189.

24. Imdad A, Ahmed Z, Bhutta ZA. Vitamin A supplementation for the prevention of morbidity and mortality in infants one to six months of age. Cochrane Database Syst Rev. 2016;9:CD007480

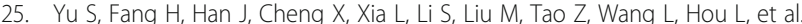
The high prevalence of hypovitaminosis $D$ in China: a multicenter vitamin $D$ status survey. Medicine. 2015:94(8):e585.

26. Wahl DA, Cooper C, Ebeling PR. A global representation of vitamin D status in healthy populations. Arch Osteoporos. 2013:8(1-2):122.

27. Li PL, Tian YJ, Wang YH, Zhang CZ, Gao J, Li YH, Li SJ. The prevalence of vitamin $\mathrm{D}$ deficiency among schoolchildren: a cohort study from Xinxiang, China. Journal of pediatric endocrinology \& metabolism : JPEM. 2015; 28(5-6):629-33.

28. Wu F, Laslett $L L$, Zhang $Q$. Threshold effects of vitamin $D$ status on bone health in Chinese adolescents with low calcium intake. J Clin Endocrinol Metab. 2015:100(12):4481-9.

29. Man PW, Meer IMVD, Lips P, Middelkoop BJC. Vitamin D status and bone mineral density in the Chinese population: a review. Arch Osteoporos. 2016;11(1):1-9.

30. Zhang HQ, Teng JH, Li Y, Li XX, He YH, He X, Sun CH. Vitamin D status and its association with adiposity and oxidative stress in school children. Nutrition. 2014;30(9):1040-4.

31. Zhang Y, Wang X, Liu Y, Qu H, Qu S, Wang W, Ren L. The GC, CYP2R1 and DHCR7 genes are associated with vitamin D levels in northeastern Han Chinese children. Swiss Med Wkly. 2012;142(2):w13636.

32. Huang Y, Li X, Wang M, Hua N, Lima A, Ying L, Sun C. Lipoprotein lipase links vitamin $D$, insulin resistance, and type 2 diabetes: a cross-sectional epidemiological study. Cardiovasc Diabetol. 2013;12(1):17.

33. Wang $M$, Yang $X$, Ren L, Li S, He X, Wu X, Liu T, Lin L, Li Y, Sun C. Biomarkers identified by urinary Metabonomics for noninvasive diagnosis of nutritional rickets. J Proteome Res. 2014;13(9):4131-42.

34. Pilz S, Dobnig H, Fischer JE, Wellnitz B, Seelhorst U, Boehm BO, März W. LoW vitamin $\mathrm{D}$ levels predict stroke in patients referred to coronary angiography. Stroke. 2008:39(9):2611.

35. Forman JP, Giovannucci E, Holmes MD, Bischoffferrari HA, Tworoger SS, Willett WC, Curhan GC. Plasma 25-hydroxyvitamin D levels and risk of incident hypertension. Hypertension. 2008;52(5):828.

36. Vaidya A, Forman JP. Vitamin D and hypertension: current evidence and future directions. Hypertension. 2010;56(5):774-9. 